\section{Accessory Nuclei and Annulate Lamellae in Hymenopteran Oocytes}

Accessory nuclei have been described in the oocytes of Hymenoptera ${ }^{1-3}$ and some other insect orders. They are present during vitellogenesis, probably originating from the oocyte nucleus ${ }^{3}$. Structurally they resemble nuclei and their electron-dense inclusions contain RNA, possibly of nuclear origin. They seem to be concerned with the control of the synthesis of albuminous yolk and afterwards perhaps with the formation of the vitelline membrane $^{3,4}$. In Nasonia vitripennis (Walk). they first appear near the nucleus of the oocyte, and spread from there through the peripheral cytoplasm (Fig. 1).
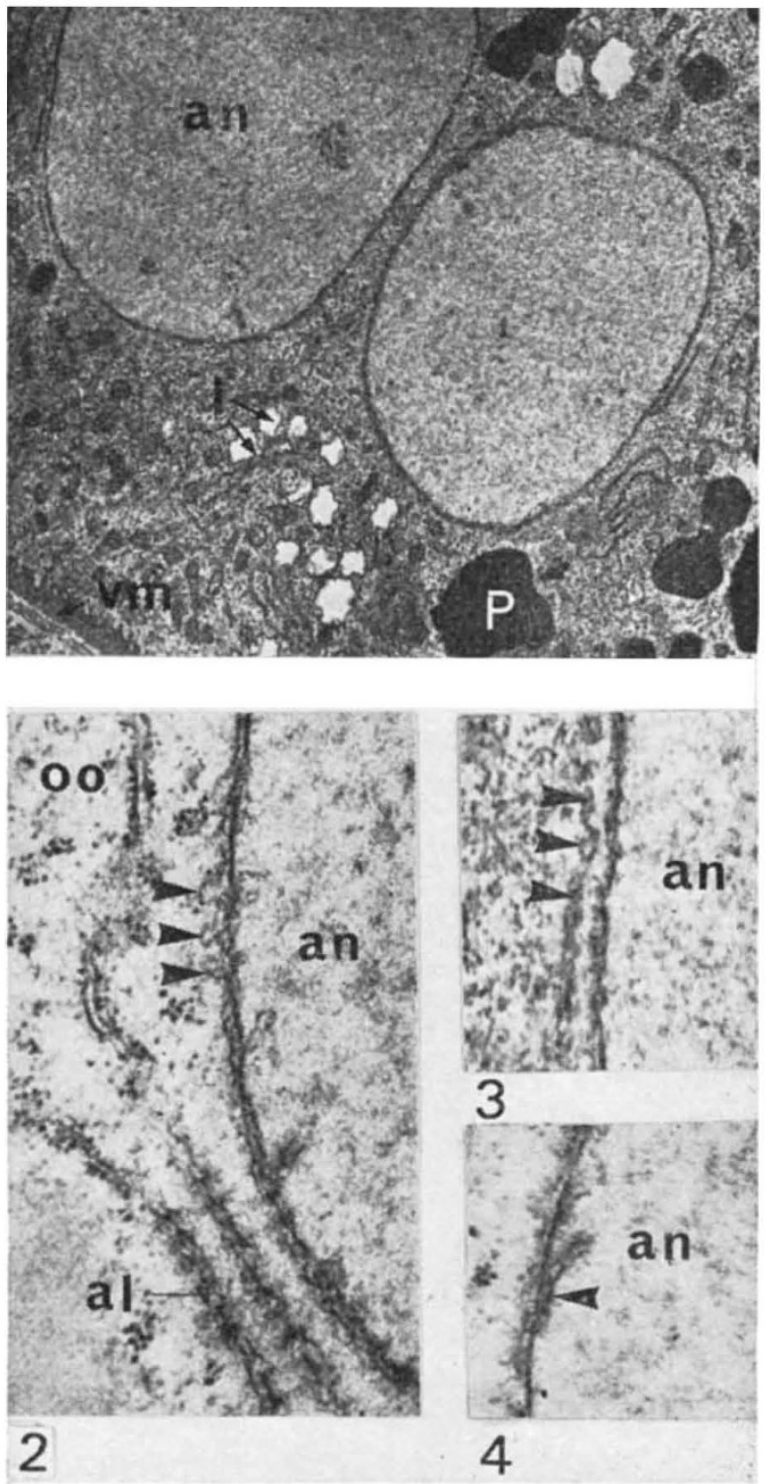

Fig. 1. Section of the periphery of an oocyte of Nasonia vitripinnis showing accessory nuclei near the vitelline membrane. (Glatarale vitelline membrane; l, Jipoid.

Fig. 2. Section of accessory nucleus of Ophion luteus showing blebbing and annulate lamellae. (Glutaraldehyde $\times 49,500$.) al, Annulate lamellae; oo, ooplasm.

Fig. 3. Section of envelope of accessory nucleus of $\boldsymbol{N}$. vitripennis showing separate and united vesicles. (Glutaraldehyde $\times 36,000$.)

Fig. 4. Section of envelope of accessory nucleus of $O$. luteus showing an intranuclear bud. (Glutaraldehyde $\times 49,500$.)
Swift ${ }^{5}$ described annulate lamellae as pairs of cytoplasmic membranes arranged in parallel stacks and with periodically spaced annuli. They have been recorded in the cytoplasm of vertebrate and invertebrate cells ${ }^{5-8}$ and in some cells they occur within the nucleoplasm ${ }^{5,6} \cdot{ }^{\circ}$ They are most abundant in rapidly growing and differentiating cells, such as oocytes, embryonic cells, spermatocytes and various kinds of tumour cells ${ }^{10,11}$. In tho salivary glands of Drosophila ${ }^{12}$, Necturus oocytes ${ }^{13}$ and adrenal cortical cells $^{8}$ of the alligator, the annulate lamellae seem to arise through the coalescence of vesicles from the nuclear membrane. Alternatively, they may be delaminated from the nuclear membrane as in the seagull adrenal ${ }^{8}$. Their function is not clear, but they are presumably involved in the transfer of information between the nucleus and the cytoplasm.

In the peripheral ooplasm of Nasonia vitripennis the accessory nuclei multiply by a process of amitotic division. Annulate lamellae then arise by the coalescence of vesicles produced by the outer membrane of the accessory nucleus envelope. A similar process has been observed in the ichneumonid, Ophion luteus Fab. (Figs, 2 and 3). Sometimes they are also budded into the nucleoplasm (Fig. 4). The annulate lamellae are either in singlo units or in stacks, and after formation they move away from the accessory nucleus. Within the stacks the lamellae are connected both with each other and with the ondoplasmic reticulum (Fig. 2). It is possible that after the first lamella has boen formed, the rest of the stack bud off it and not the nuclear membrane (Fig. 2). Noar the site of origin of the lamellae vesicles occur between the membranes of the nuclear envelope, which suggests that nuclear material is being extruded presumably to the lamellae. This would support the view that their function is to extend the influence of the nucleus, started by the budding off of the accessory nuclei. This would be very important in a highly active cell, particularly if, as in the oocyte of insects, movemont within the cell is impeded by numerous yolk globules. Their proximity to the accessory nuclear membrane supports the view that annulate lamellae are of nuclear origin and not specialized regions of the endoplasmic reticulum ${ }^{9,13}$. Lipoid yolk first appears in their vicinity and perhaps one of their functions is to contribute to its formation.

P. E. KING

J. G. RICHARDS

Department of Zoology,

University College,

Swansea.

Received February 28; revised March 20, 1968.

${ }^{1}$ Hegner, R. W., J. Morphol., 26, 495 (1915).

2 Pilm N. B. Opusc. Entomol. 7, I (1948).

${ }^{3}$ Hopkins, C. R., Quart. J. Microsc. Sci., 105, 475 (1964).

- Cruikshank, W. J., Nature, 201, 734 (1964).

${ }^{\circ}$ Swift, H. H., J. Biophys. Biochem. Cytol., 2, Suppl., 415 (1956).

- Kessel, R, G., Z. Zellforsch., 63, 37 (1964).

? Merriam, R. W., J. Biophys, Biochem. Cytol., 5, 117 (1959).

" Harrison, G. A., J. Ultrastruct. Res., 14, 158 (1966).

'Doolin, P. E., Barron, K. D., and Seber, A., Anat. Rec., 159, 219 (1967).

${ }^{10}$ Chambers, V. C., and Weiser, R. S., J. Cell. Biol.,21, 133 (1904).

11 Kumegawa, M., Cattoni, M., and Rose, G. G., J. Cell. Biol., 34, 897 (1967).

12 Gay, H., J. Biophys. Biochem. Cytol., 2, Suppl., 407 (1956).

${ }^{13}$ Kessel R. G., J. Cell. Biol., 19, 391 (1963).

\section{Chromosome Abnormalities and Psychotropic Drugs}

DURING a study of chromosome abnormalities in five patients treated with $d$-lysergic acid diethylamido (LSD) we examined thirty patients in a mental hospital and ten hospital staff members as controls. The frequency of gaps was significantly higher in the thirty patients than in the staff members group $\left(\chi^{2}=6.859, P<0.01\right)$. When we divided the control group of patients into those treated 